\title{
Membrane lipids of mesophilic anaerobic bacteria thriving in peats have typical archaeal traits
}

Johan W. H. Weijers, ${ }^{1 *}$ Stefan Schouten, ${ }^{1}$ Ellen C. Hopmans, ${ }^{1}$ Jan A. J. Geenevasen, ${ }^{2}$ Olivier R. P. David, ${ }^{2}$ Joanna M. Coleman, ${ }^{3}$ Rich D. Pancost ${ }^{3}$ and Jaap S. Sinninghe Damsté ${ }^{1}$ Royal Netherlands Institute for Sea Research (NIOZ), Department of Marine Biogeochemistry and Toxicology, PO Box 59, 1790 AB Den Burg - Texel, the Netherlands.

${ }^{2}$ University of Amsterdam, van 't Hoff Institute for Molecular Sciences, Nieuwe Achtergracht 129, 1018 WS Amsterdam, the Netherlands.

${ }^{3}$ University of Bristol, Organic Geochemistry Unit, Cantock's Close, BS8 1TS Bristol, UK.

\section{Summary}

The 16S ribosomal DNA based distinction between the bacterial and archaeal domains of life is strongly supported by the membrane lipid composition of the two domains; Bacteria generally contain dialkyl glycerol diester lipids, whereas Archaea produce isoprenoid dialkyl glycerol diether and membranespanning glycerol dialkyl glycerol tetraether (GDGT) lipids. Here we show that a new group of ecologically abundant membrane-spanning GDGT lipids, containing branched instead of isoprenoid carbon skeletons, are of a bacterial origin. This was revealed by examining the stereochemistry of the glycerol moieties of those branched tetraether membrane lipids, which was found to be the bacterial 1,2-di-O-alkyl-snglycerol stereoconfiguration and not the 2,3-di-Oalkyl-sn-glycerol stereoconfiguration as in archaeal membrane lipids. In addition, unequivocal evidence for the presence of cyclopentyl moieties in these bacterial membrane lipids was obtained by NMR. The biochemical traits of biosynthesis of tetraether membrane lipids and the formation of cyclopentyl moieties through internal cyclization, which were thought to be specific for the archaeal lineage of descent, thus also occur in the bacterial domain of life.

Received 27 July, 2005; accepted 16 September, 2005. *For correspondence. E-mail jweijers@nioz.nl; Tel. (+31) 222 369567; Fax (+31) 222319674.

\section{Introduction}

The phylogenetic distinction between Archaea and Bacteria (Woese et al., 1990) is supported by distinct differences in their core membrane lipid composition. Especially the chain architecture (isoprenoidal versus $n$ alkyl) and the stereochemistry of the glycerol backbone (2,3- versus 1,2-di-O-alkyl-sn-glycerol for Archaea and Bacteria respectively; Kates, 1978) are strong lipidtaxonomic indicators, for which, to the best of our knowledge, no exceptions have been reported yet. Considering the stereochemistry of the glycerol backbone, it is known that only two enzymes are involved in introducing either of the stereoconfigurations (2,3- or 1,2-di-O-alkyl-snglycerol) in the glycerol moiety of membrane lipids. Those two stereospecific enzymes [G-1-P-dehydrogenase (Nishihara and Koga, 1995) for Archaea and G-3-Pdehydrogenase (Kito and Pizer, 1969) for Bacteria] are completely different in their amino acid sequence and are even thought to be one of the main reasons for the separate evolution of the domains of Archaea and Bacteria (Koga et al., 1998).

Other lipid-taxonomic indicators which distinguish Archaea from Bacteria are the bond type (ether versus ester bonds) and the membrane lipid structure (membrane spanning versus bi-layered). However, some exceptions are known, especially in the case of thermophilic bacteria. Membrane lipids containing ether bound glycerols (e.g. 1; see Appendix for structures) have, for example, been found in the hyperthermophilic bacteria Thermodesulfotobacterium commune (Langworthy et al., 1983), Aquifex pyrophylus (Huber et al., 1992) and Ammonifex degensii (Huber et al., 1996). Diether membrane lipids (e.g. 2) were also found in yet unknown, non-thermophilic sulfate-reducing bacteria of a microbial consortium capable of anaerobic methane oxidation (Pancost et al., 2001) and recently in Candidatus ' $\mathrm{K}$. stuttgartiensis' and Candidatus 'B. anammoxidans', two new members of the order Planctomycetes (Sinninghe Damsté et al., 2002b). These latter two strains and the sulfate-reducing bacteria Desulfosarcina variabilis and Desulforhabdus amnigenus (Rütters et al., 2001) also produce membrane lipids (e.g. 3) with both an ester and ether bound alkyl chain within one glycerol membrane lipid. In the bacterial domain, membrane-spanning lipids 
have also been inferred for some species. The thermophilic anaerobic Thermotoga maritima, for example, produces 13,14-dimethyloctacosane and 15,16dimethyltriacontane carbon chains (Carballeira et al., 1997) of which the latter one is found to be ether bound to one glycerol unit (4) (De Rosa et al., 1988). Tetraester membrane lipids containing $\alpha, \omega$-13,16-dimethyloctacosane moieties (5) were identified in Thermoanaerobacter ethanolicus (Jung et al., 1994; Lee et al., 2002). Except for the monoether found in Thermotoga maritima, a combination of both ether bonds and membranespanning carbon chains has so far never been encountered in Bacteria, specifically not in a tetraether configuration like in Archaea (e.g. 6). Additionally to those distinguishing features, the presence of cyclopentyl moieties is another characteristic which is, to the best of our knowledge, only found in the alkyl chains of archaeal membrane lipids and are absent in those of Bacteria.

A few years ago, a new group of membrane lipids, branched glycerol dialkyl glycerol tetraethers (GDGTs) $(7,8,9)$ were found in peat bogs (Schouten et al., 2000; Pancost and Sinninghe Damsté, 2003; Hopmans et al., 2004) and soils (J. Weijers, S. Schouten, J. Sinninghe Damsté, unpubl. results) and unambiguously identified by NMR (Sinninghe Damsté et al., 2000). Strikingly, these new GDGTs differ from known archaeal tetraether lipids (e.g. 6) in that the alkyl moieties are not comprised of isoprenoid units but of branched carbon chains. Branched GDGTs with cyclopentyl moieties were tentatively identified as well $(10,11)$ (Schouten et al., 2000). Hence, these branched GDGTs contain a mixture of archaeal (membrane spanning tetraether structure and cylcopentyl moieties) and bacterial (branched carbon chains) characteristics. It is thus uncertain to which domain of life the organism biosynthesizing these branched GDGT lipids belongs.

Application of molecular ecological tools to ascertain the origin of these enigmatic components is hampered by the huge phylogenetic diversity of microorganisms in peats and soils (up to an estimated $10^{4}$ different species in one small sample; Torsvik et al., 2002) and the bias of microbiological culture techniques. Examination of the stereochemical characteristics of the membrane lipids provides a good alternative to distinguish between an archaeal and bacterial origin. To this end, the stereochemistry of the glycerol backbone of a branched GDGT (8) was unambiguously established. Furthermore, the structure of a branched GDGT with the putative cyclopentyl moiety (10) was also determined. This shows the presence of distinct archaeal traits in anaerobic bacteria thriving in soils and peats. Finally, by analysing two peat depth profiles for their branched GDGT content, information is gained about the habitat of the source organisms.

\section{Results}

\section{Structural identification of GDGTs in peats}

A high-performance liquid chromatography (HPLC) base peak chromatogram of a sample from the Saxnäs Mosse bog (Sweden) shows high abundances of the branched GDGTs 7 and 8 and, to a lesser extent, GDGT 9 (Fig. 1). Concentrations of the ring-containing GDGTs (10-15) are generally $10 \%$ or less than those of GDGTs 7-9. So far, only the structures of GDGTs 7 and 8 (Sinninghe Damsté et al., 2000) have been fully elucidated by NMR. It was therefore decided to attempt to fully characterize a GDGT containing a cyclopentyl moiety.

Preparative HPLC on the bulk peat sample from Étang de la Gruère bog (Switzerland) resulted in c. $3 \mathrm{mg}$ of isolate in which the ring-containing GDGT 10 accounts for $c$. $88 \%$, the remainder being minor amounts of GDGT 8 (9\%),

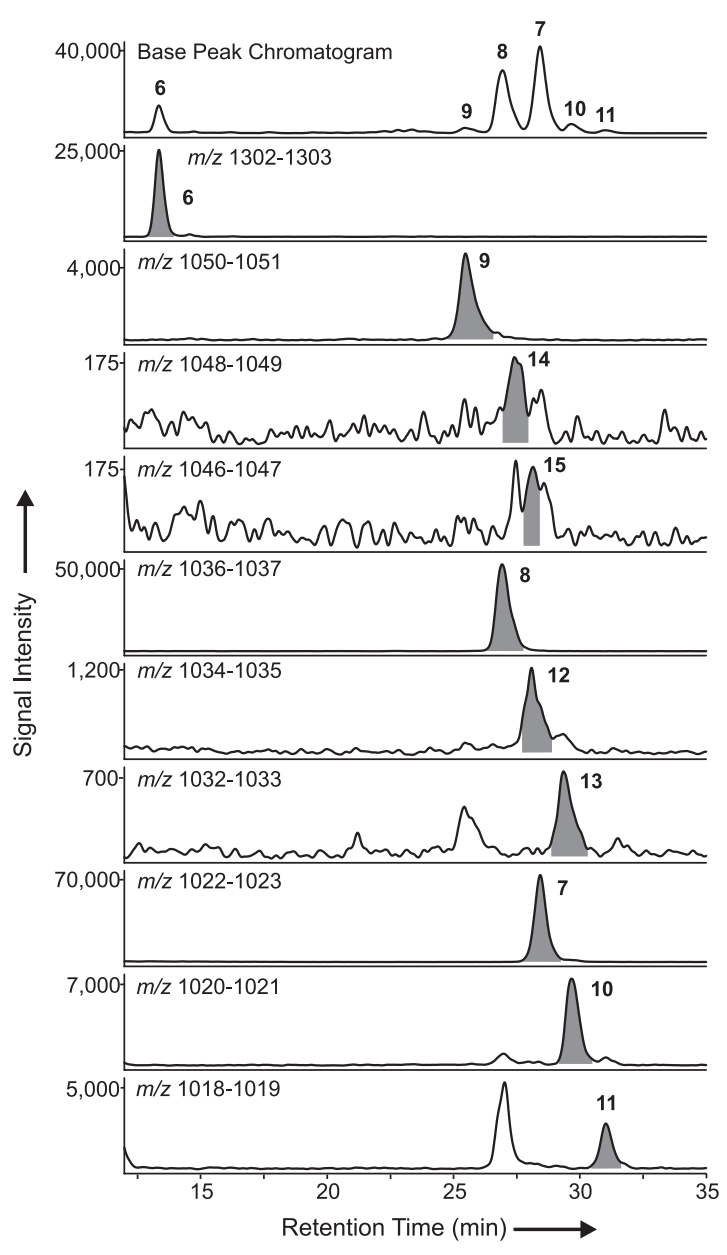

Fig. 1. Partial HPLC/MS base peak chromatogram and mass chromatograms of the protonated molecule plus first isotope peak of the different GDGTs in a $43 \mathrm{~cm}$ deep sample from the Saxnäs Mosse peat bog. Numbers refer to the structures in the Appendix. The highest peak at the $m / z 1018$ trace is a $[M+1]-18\left(\mathrm{H}_{2} \mathrm{O}\right)$ fragment from $\mathrm{m} / \mathrm{z} 1036$ (GDGT 8). Similarly, the peak in the $\mathrm{m} / \mathrm{z} 1032$ trace in front of GDGT 13 represents the [M+1]-18 fragment of GDGT 9. 
GDGT 7 (1\%) and GDGT 12 (1\%). The ${ }^{1} \mathrm{H}-\mathrm{NMR}$ spectrum of this isolate is extremely complex even if measured at $600 \mathrm{MHz}$. In the 3.4-3.7 ppm region, multiplets accounting for 18 protons are observed (Table 1). These represent the protons of the two glycerol units and the first and ultimate methylene units of the alkyl moieties bound via the ether linkages. The same signals were observed in the ${ }^{1} \mathrm{H}-\mathrm{NMR}$ spectra of GDGT 7 and 8 in an earlier study (Sinninghe Damsté et al., 2000). At c. 2.2 ppm a broad singlet representing the two hydroxy groups is found. At $0.85 \mathrm{ppm}$ two doublets occur, representing three methyl groups, whereas the spectra of GDGT 7 and $\mathbf{8}$ showed only one doublet representing four methyl groups. Another difference with these ${ }^{1} \mathrm{H}-\mathrm{NMR}$ spectra is the presence of a multiplet between 1.7 and $1.8 \mathrm{ppm}$ representing four protons.

The ${ }^{13} \mathrm{C}$-NMR spectrum of GDGT 10 reveals three primary, 56 secondary and seven tertiary atoms (Table 1). APT, DEPT90 and DEPT135 experiments were used to assess the multiplicity of these carbon atoms. The ${ }^{13} \mathrm{C}$ NMR spectrum did not show 66 resolved signals because many carbon atoms are either strictly or effectively equivalent. Assignments of the carbon atoms is based on comparison with the ${ }^{13} \mathrm{C}-\mathrm{NMR}$ data of GDGT 7, 8 and 16 (Sinninghe Damsté et al., 2000; 2002a), in combination

Table 1. ${ }^{13} \mathrm{C}$ - and ${ }^{1} \mathrm{H}-\mathrm{NMR}$ data used for the structural identification of GDGT 10.

\begin{tabular}{|c|c|c|c|c|}
\hline \multirow[b]{2}{*}{ Carbon atom ${ }^{a}$} & \multicolumn{3}{|c|}{ Carbon shift $(p p m)^{b}$} & \multirow[b]{2}{*}{ Proton shift $(\mathrm{ppm})^{\mathrm{c}}$} \\
\hline & $\mathrm{CH}$ & $\mathrm{CH}_{2}$ & $\mathrm{CH}_{3}$ & \\
\hline $\mathrm{A} 1, \mathrm{~B} 1^{\prime}$ & & 71.77 & & $3.41(4 \mathrm{H}, \mathrm{m})$ \\
\hline $\mathrm{A} 1^{\prime}, \mathrm{B} 1$ & & 70.41 & & $3.58(2 \mathrm{H}, \mathrm{m}), 3.51(2 \mathrm{H}, \mathrm{m})$ \\
\hline A2, B2' & & 29.40 & & $1.53(4 \mathrm{H}, \mathrm{m})$ \\
\hline $\mathrm{A}^{\prime}, \mathrm{B} 2$ & & 29.98 & & $1.55(4 \mathrm{H}, \mathrm{m})$ \\
\hline A3, B3' & & 26.09 & & 1.30 \\
\hline $\mathrm{A} 3^{\prime}, \mathrm{B} 3$ & & 26.06 & & 1.30 \\
\hline $\mathrm{A} 4, \mathrm{~A} 4^{\prime}, \mathrm{B} 4, \mathrm{~B} 4^{\prime}$ & & c. 29.6 & & c. 1.24 \\
\hline $\mathrm{A} 5, \mathrm{~A}^{\prime}, \mathrm{B} 5, \mathrm{~B} 5^{\prime}$ & & c. 29.6 & & c. 1.24 \\
\hline $\mathrm{A} 6, \mathrm{~A}^{\prime}, \mathrm{B} 6, \mathrm{~B} 6^{\prime}$ & & c. 29.6 & & c. 1.24 \\
\hline $\mathrm{A} 7, \mathrm{~A} 7^{\prime}, \mathrm{B} 7^{\prime}$ & & c. 29.6 & & c. 1.24 \\
\hline B7 & & 29.86 & & c. 1.24 \\
\hline $\mathrm{A} 8, \mathrm{~A} 8^{\prime}, \mathrm{B} 8^{\prime}$ & & c. 29.6 & & c. 1.24 \\
\hline B8 & & 28.62 & & 1.22 \\
\hline $\mathrm{A} 9, \mathrm{~A} 9^{\prime}, \mathrm{B} 9^{\prime}$ & & c. 29.6 & & c. 1.24 \\
\hline B9 & & $36.77^{d}$ & & 1.23 \\
\hline $\mathrm{A} 10, \mathrm{~A} 10^{\prime}, \mathrm{B} 10^{\prime}$ & & 30.05 & & 1.21 \\
\hline B10 & & & $38.76^{e}$ & 1.80 \\
\hline $\mathrm{A} 11, \mathrm{~A} 11^{\prime}$ & & 27.05 & & 1.23 \\
\hline B11 & & $33.14^{f}$ & & $1.75(\mathrm{eq}), 1.03(\mathrm{ax})$ \\
\hline B11' & & 27.01 & & 1.23 \\
\hline $\mathrm{A} 12, \mathrm{~A} 12^{\prime}$ & & 37.15 & & 1.06 \\
\hline B12 & & 33.14 & & $1.75(\mathrm{eq}), 1.03(\mathrm{ax})$ \\
\hline $\mathrm{B} 12^{\prime}$ & & 36.98 & & 1.25 \\
\hline $\mathrm{A} 13, \mathrm{~A} 13^{\prime}$ & & & 33.05 & 1.31 \\
\hline $\mathrm{B} 13$ & & & $39.02^{\mathrm{g}}$ & 1.76 \\
\hline B13' & & & 32.85 & 1.32 \\
\hline $\mathrm{A} 14, \mathrm{~A} 14^{\prime}$ & & 34.35 & & $1.07,1.22$ \\
\hline $\mathrm{B} 14$ & & $34.00^{\mathrm{h}}$ & & 1.23 \\
\hline${\mathrm{B} 14^{\prime}}^{\prime}$ & & 35.85 & & $1.05,1.23$ \\
\hline $\mathrm{A} 15, \mathrm{~A} 15^{\prime}$ & 19.79 & & & $0.858(6 \mathrm{H}, \mathrm{d})$ \\
\hline B15 & & 38.67 & & 1.30 \\
\hline B15' & 19.86 & & & $0.854(3 \mathrm{H}, \mathrm{d})$ \\
\hline $\mathrm{C} 1, \mathrm{C}^{\prime}$ & & 71.11 & & $3.49(2 \mathrm{H}, \mathrm{m}), 3.46(2 \mathrm{H}, \mathrm{m})$ \\
\hline $\mathrm{C} 2, \mathrm{C} 2^{\prime}$ & & & 78.39 & $3.49(2 \mathrm{H}, \mathrm{m})$ \\
\hline C3, C3' & & 63.05 & & $3.68(2 \mathrm{H}, \mathrm{dd}), 3.58(2 \mathrm{H}, \mathrm{m})$ \\
\hline $\mathrm{OH}$ & & & & $2.10(2 \mathrm{H}, \mathrm{bs})$ \\
\hline
\end{tabular}

a. Numbering refers to GDGT 10 in the Appendix.

b. Determined by APT, DEPT90 and DEPT135.

c. Mainly obtained from the HMQC spectrum.

d. In good agreement with the $\delta=36.83$ calculated from data of a cyclopentane-containing isoprenoidal GDGT (Sinninghe Damsté et al., 2002a) and the additivity principle.

e. In good agreement with the $\delta=38.80$ calculated from data of a cyclopentane-containing isoprenoidal GDGT (Sinninghe Damsté et al., 2002a) and the additivity principle.

f. In good agreement with the $\delta=33.08$ calculated from data of a cyclopentane-containing isoprenoidal GDGT (Sinninghe Damsté et al., 2002a) and the additivity principle.

g. In good agreement with the $\delta=39.04$ calculated from the shift of carbon atom B10 and the additivity principle.

h. In agreement with the $\delta=34.42$ calculated from the shift of carbon atom B9 and the additivity principle. 
Table 2. Chemical shift (in ppm relative to $\mathrm{CFCl}_{3}$ ) of the $\mathrm{CF}_{3}$ group of the Mosher products of the reaction of the branched GDGT 8, 1,2-di-Odihexadecyl-rac-glycerol, 1,2-di-O-dihexadecyl-sn-glycerol and the isoprenoid GDGT 16 with the S- and R-Mosher acid chlorides. Between brackets the relative abundance of the signal is given.

\begin{tabular}{lllll}
\hline & GDGT 8 & 1,2-di-O-dihexadecyl-rac-glycerol & 1,2-di-O-dihexadecyl-sn-glycerol & GDGT 16 \\
\hline S-Mosher acid chloride & $-73.212(100 \%)$ & $-73.106(50 \%)$ & $-73.170(100 \%)$ & $-73.048(100 \%)$ \\
R-Mosher acid chloride & $-73.129(100 \%)$ & nd & $-73.106(100 \%)$ & $-73.137(100 \%)$ \\
\hline
\end{tabular}

nd, not determined.

with HMQC and HMBC experiments. Many shifts observed in the ${ }^{13} \mathrm{C}$-NMR spectrum are identical to those reported for GDGT 7 (Sinninghe Damsté et al., 2000), confirming their close structural relationship. The major difference is that one methyl group (i.e. carbon atom B15) is absent and is part of a cyclopentyl moiety, as suggested previously on the basis of mass spectral analyses (Schouten et al., 2000). This results in characteristic shifts for carbon atoms B7-B15 and B13'-B15'-that are different from the shifts observed for these carbon atoms in GDGT 7. Both the ${ }^{13} \mathrm{C}$ and ${ }^{1} \mathrm{H}$ shifts for the atoms of the cyclopentyl moiety are consistent with literature data (Sinninghe Damsté et al., 2002a). The ultimate proof for this structural assignment is the observed correlation of the protons of carbon atom B15 with the carbon atoms B9, $B 10, B 11$ and B12, B13, and B14 in the HMBC spectrum. The structures of the other ring-containing GDGTs (11-15), all possessing one or two cyclopentyl moieties, were deduced from the characteristic $[\mathrm{M}+\mathrm{H}]^{+},[\mathrm{M}+\mathrm{H}]^{+}-18$ (water loss) and $[\mathrm{M}+\mathrm{H}]^{+}-74$ (glycerol loss) pattern in their mass spectra, their retention time relative to their 'parent' GDGTs (7-9) and the structure of GDGT 10.

\section{Stereoconfiguration of the glycerol backbone of GDGTs in peats}

The isolate of GDGT 8, obtained previously from the Holocene Bargerveen peat bog (the Netherlands)

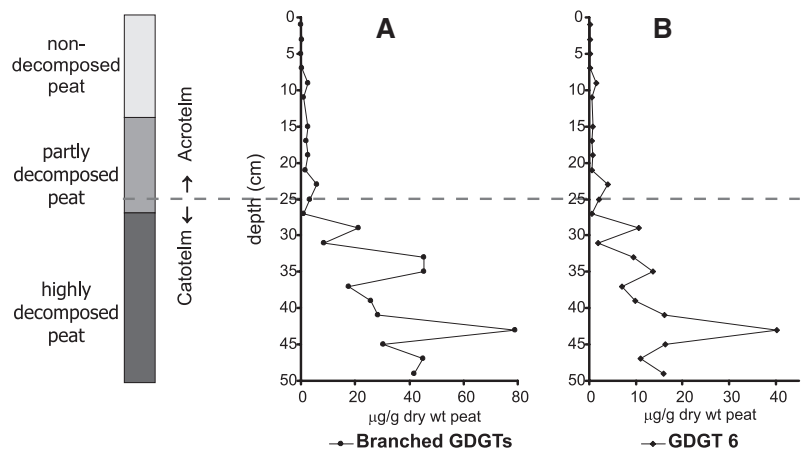

Fig. 2. Concentrations of $(A)$ the branched GDGTs 7-9 (average value) and (B) GDGT 6 against depth in a peat core from the Saxnäs Mosse, Sweden, together with a schematic decomposition profile of the peat core. The acrotelm layer is the zone in which the water table fluctuates and the catotelm layer is the zone of permanent water saturation.
(Sinninghe Damsté et al., 2000), was used here to determine the stereochemistry of the glycerol backbone. To this end, this GDGT was reacted with the S- and R- $\alpha$ methoxy- $\alpha$-(trifluoromethyl)phenylacetyl chlorides to give the so-called Mosher ester (Dale and Mosher, 1973) and the chemical shift of the trifluoromethyl group was investigated with ${ }^{19} \mathrm{~F}-\mathrm{NMR}$. The Mosher esters of this branched GDGT 8 gave comparable chemical shifts for the $\mathrm{CF}_{3}$ group as the S- and R-Mosher acid derivatives of the commercially available 1,2-di-O-dihexadecyl-snglycerol, but opposite of those of the Mosher esters of the isoprenoid GDGT 16 isolated from Sulfolobus acidocaldarius (Sinninghe Damsté et al., 2002a) which possesses the 2,3-di-O-alkyl-sn-glycerol stereoconfiguration (Table 2). This shows that the branched GDGT 8, found in peats and soils, possess the bacterial 1,2-di-O-alkylsn-glycerol and not the archaeal 2,3-di-O-alkyl-snglycerol stereoconfiguration.

\section{Glycerol dialkyl glycerol tetraether profiles in peats}

Two peat cores were analysed for their branched GDGT content and for GDGT 6, a commonly found isoprenoid GDGT (Figs 2 and 3). Branched GDGTs 7-15 are all detected in the Saxnäs Mosse core (see also Fig. 1). In the Bolton Fell Moss core, only GDGTs 7, 8 and 10-13 could be detected, whilst GDGTs 9, 14 and 15 were below detection limit using high temperature - gas chromato-

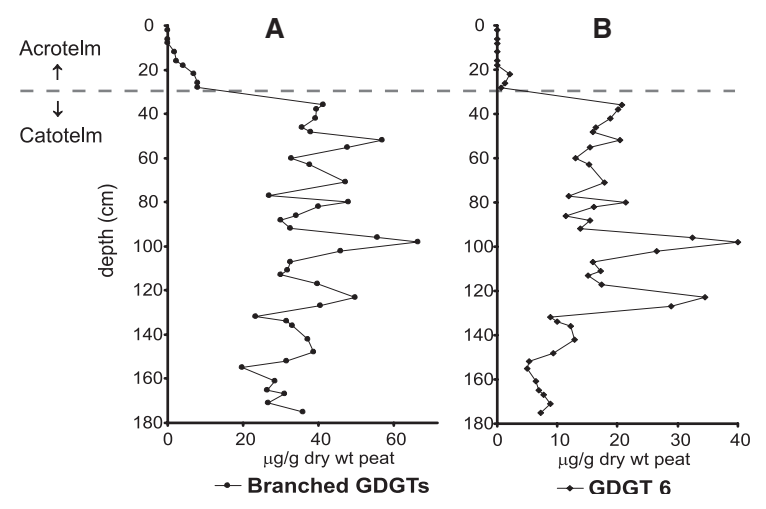

Fig. 3. Concentrations of (A) the branched GDGTs 7 and 8 (average value) and (B) GDGT 6 against depth in a peat core from the Bolton Fell Moss, Cumbria, England. 
graphy (HT-GC). Concentrations of the branched GDGTs in the Saxnäs Mosse are very low in the upper $8 \mathrm{~cm}$ $\left[0.2 \mu \mathrm{g} \mathrm{g}^{-1}\right.$ dry weight (wt) peat] and slightly higher, around $3 \mu \mathrm{g} \mathrm{g}{ }^{-1}$ dry wt peat, between 8 and $28 \mathrm{~cm}$ depth. Branched GDGT concentrations are highest below $28 \mathrm{~cm}$ with an average concentration of $35 \mu \mathrm{g} \mathrm{g}{ }^{-1}$ dry wt peat. The Bolton Fell Moss profile shows a similar pattern; branched GDGT concentrations are below detection limit in the upper $10 \mathrm{~cm}$ and are about $5 \mu \mathrm{g} \mathrm{g}^{-1}$ dry wt peat between 10 and $28 \mathrm{~cm}$. Below $28 \mathrm{~cm}$ the average concentration is much higher at $37 \mu \mathrm{g} \mathrm{g}^{-1}$ dry wt peat. In the Bolton Fell Moss core, which extends to $175 \mathrm{~cm}$ depth, a trend to slightly lower concentrations can be observed from c. $120 \mathrm{~cm}$ downward.

The concentrations of GDGT 6 in both cores are about two times lower compared with those of the branched GDGTs. In the Saxnäs Mosse, concentrations of GDGT 6 are $0.2 \mu \mathrm{g} \mathrm{g}^{-1}$ dry wt peat in the upper $8 \mathrm{~cm}, 1.2 \mu \mathrm{g} \mathrm{g}^{-1}$ dry wt peat between 8 and $28 \mathrm{~cm}$ and $13 \mu \mathrm{g} \mathrm{g}^{-1}$ dry wt peat between 28 and $50 \mathrm{~cm}$. For the Bolton Fell Moss core, those concentrations are below detection limit for the upper $10 \mathrm{~cm}$ and 0.7 and $16 \mu \mathrm{g} \mathrm{g}^{-1}$ dry wt peat for the intervals $10-28$ and $28-175 \mathrm{~cm}$ respectively. As is observed for the branched GDGTs, GDGT 6 decreases in concentration in the lower $50 \mathrm{~cm}$ of the Bolton Fell Moss core.

\section{Discussion}

\section{A bacterial origin for branched GDGTs in peat}

The elucidation of the stereochemistry of the glycerol backbone of GDGT 8 as the 1,2-di-O-alkyl-sn-glycerol stereoconfiguration strongly indicates that branched GDGTs encountered in peats are biosynthesized by members of the domain of Bacteria. The stereochemical evidence is particularly strong because it is highly unlikely that Archaea would biosynthesize membrane lipids with a bacterial stereoconfiguration as the enzymes responsible for introducing the stereoconfiguration are thought to form the basis for the divergent evolution of the Bacteria and the Archaea (Koga et al., 1998). A possible archaeal origin would therefore mean a thorough reconsideration of the current ideas on early evolution and lateral gene transfer (LGT). A bacterial origin of the branched tetraethers is also consistent with the chain architecture ( $n$-alkyl instead of isoprenoid). Furthermore, ether bonds as well as membrane spanning alkyl chains have previously been reported in some Bacteria (Langworthy et al., 1983; De Rosa et al., 1988; Lee et al., 2002). Considering the above stated arguments, the presence of cylcopentyl moieties in the alkyl chains, which, to the best of our knowledge, has so far never been reported before in core membrane lipids of Bacteria, should therefore be regarded as the first report of the occurrence of cyclopentyl moieties in Bacteria.

\section{Biosynthetic pathway}

The exact functional role of these branched GDGTs is as yet unclear, but they are likely membrane-spanning lipids just like archaeal GDGTs and may provide the cell membrane with a higher degree of stability. This assumption is supported by the calculated length of the branched GDGTs, which is $c .34 \AA$ versus $37 \AA$ for the isoprenoid GDGT $6\left(1 \AA=10^{-10} \mathrm{~m}\right.$; determined for an individual GDGT in a minimal energy mode between the chiral carbon atoms of the two glycerol moieties; CS ChemDraw Pro software, CambridgeSoftCorporation, MA, USA). This is of the same order of magnitude as the thickness of a black lipid monolayer membrane composed of tetraethers of the archaeon Thermoplasma acidophilum, which is, because stacked in a membrane and therefore smaller, determined at 25-30 A (Stern et al., 1992). Due to the similarity in the overall molecular structure of the branched GDGTs and the archaeal isoprenoid GDGTs (e.g. 6), a schematic biosynthetic pathway is postulated for the branched GDGTs, which to a certain extent resembles that of isoprenoid GDGTs (Boucher et al., 2004) (Fig. 4). The first step of this pathway involves the establishment of the sn-glycerol-3-phosphate backbone out of dihydroxyacetone phosphate (DHAP) by G-3-P dehydrogenase (Fig. 4). In this step Bacteria differentiate themselves from the Archaea, who use G-1-P dehydrogenase to form the opposite sn-glycerol-1-phosphate backbone out of DHAP. In step 2 and 3 two isopentadecane moieties are connected via an ether bond at the $s n-1$ and $s n-2$ positions of the glycerophosphate backbone, creating a diether. The existence of these steps seems to be plausible as similar diethers (e.g. 1) are found in several bacteria, such as Thermodesulfotobacterium commune (Langworthy et al., 1983), Aquifex pyrophylus (Huber et al., 1992) and Ammonifex degensii (Huber et al., 1996). The enzymes carrying out the ether bond formation in steps 2 and 3 are unknown and cannot be the same as those in the biosynthesis of diethers in Archaea as they have to cope with the opposite stereoconfiguration of the glycerophosphate backbone. The fourth step in the proposed pathway is similar to that of the biosynthesis of isoprenoid GDGTs and involves the head-to-head coupling of two glycerol dialkyl diethers to form a glycerol di-alkyl glycerol tetraether. Although the details of this step as well as the enzyme(s) involved are as yet unknown for the Archaea as well, the existence of this step in the archaeal pathway has been proven indirectly by labelling experiments and by inhibiting this step with terbinafine (Eguchi et al., 2003; Nemoto et al., 2003). The responsible enzyme for this coupling process could be the same in both Archaea and Bacteria 


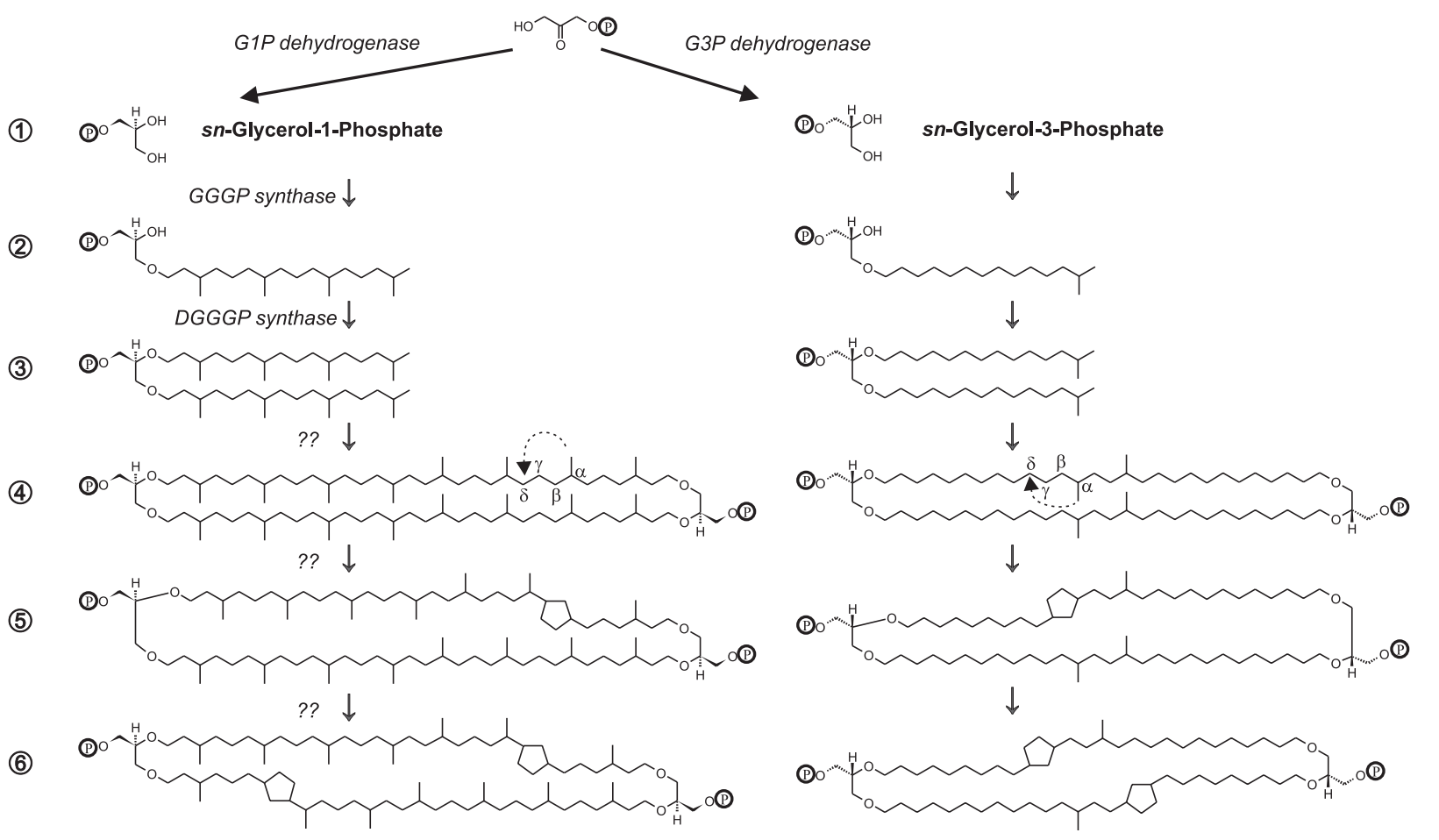

Fig. 4. Schematic representation of the postulated biosynthetic pathway for the branched GDGTs compared with the biosynthetic pathway for isoprenoid GDGTs (modified after Boucher et al., 2004). P, phosphate; DHAP, dihydroxyacetone phosphate; GGGP, geranylgeranylglyceryl phosphate; DGGGP, digeranylgeranylglyceryl phosphate. Double bonds, which are, at least in the isoprenoid pathway, present in all but the last stages, have been omitted for sake of simplification. For isoprenoid GDGTs the formation of cyclopentyl moieties can continue up to eight rings.

as the tails of both carbon chains are structurally identical (i.e. isoprenoid versus iso-branched). The next steps in the biosynthesis of both types of tetraethers comprise the formation of cyclopentyl moieties. In the archaeal tetraethers, formation of such a cyclopentyl moiety takes place via an internal cyclization of a methyl branch with a $\delta$ carbon (De Rosa et al., 1977). It is likely that the formation of cyclopentyl moieties in the branched GDGTs takes place in a similar fashion and based on the structural similarity, this cyclization process might be carried out by similar enzymes as well. It might be possible that the bacteria producing the branched GDGTs acquired the enzymes for the head-to-head coupling and the formation of a cyclopentyl moiety via lateral gene transfer from Archaea, or vice versa, a process which has been shown to occur between thermophilic Archaea and Bacteria (Nelson et al., 1999).

\section{Ecology}

Analyses of two peat cores reveal that the branched GDGTs (7-9) are abundant in the continuously water saturated and consequently anoxic part of the peat bogs (Figs 2 and 3). This suggests that anaerobic bacteria are the source of the branched GDGTs. The low abundances of GDGTs in the upper part of the profiles can probably be explained by alternating oxic and anoxic conditions, due to a moving water table. Concentrations of the branched GDGTs are about twice as high compared with the isoprenoid GDGT 6, which in these settings is most likely derived from methane-producing, anaerobic archaea (Tornabene and Langworthy, 1979; Pancost et al., 2000). This is the same ratio as was found for biphytane and dimethyloctacosane in the Bargerveen peat bog (the Netherlands) after release of the alkyl moieties from the GDGTs by ether cleavage (Pancost and Sinninghe Damsté, 2003). Methanogenic archaea are known to play a major role in the carbon cycle in peat bogs and cell counts of Archaea in a Siberian peat bog showed that their relative abundance increases with depth up to $36 \%$ of the total microbial community (Kotsyurbenko et al., 2004). Therefore, the relatively high abundance of branched GDGTs indicates that the anaerobic bacteria producing them might also form an ecologically significant part of the microbial population. In both peat cores the pattern of the concentration profile of the branched GDGTs (7-9) resembles to a great extent the concentration profile of the isoprenoid GDGT 6. This suggests that both (groups of) organisms use the same substrates and/ or catalyse the same processes. Until the bacteria which 
produce the branched GDGTs have been fully identified, however, any suggestion about their role in the biodegradation of organic matter remains speculative.

\section{Functional role of branched GDGTs}

Besides being a relict from thermophilic ancestors, the presence of branched GDGTs in mesophilic bacteria could as well be an adaptation to the environment in which these organisms thrive. It is assumed that the formation of a monolayer cell membrane by membrane-spanning tetraethers is an adaptation of Archaea to more extreme conditions in order to maintain a certain degree of stability in the membrane (Van de Vossenberg et al., 1998). At first sight, the discovery of GDGTs in the ubiquitous mesophilic aquatic Crenarchaeaota (Hoefs et al., 1997; DeLong et al., 1998; Schouten et al., 2000; Sinninghe Damsté et al., 2002a) refutes this assumption. Those Crenarchaeaota, however, have been shown to adapt their membrane to the cooler environment by the formation of an additional unique GDGT lipid, crenarchaeol (17), containing a cyclohexyl moiety (Sinninghe Damsté et al., 2002a). The presence of GDGT 6 in a peat also seems to refute the assumption that GDGTs are related to extreme environments. A peat environment, however, has $\mathrm{pH}$ values which are generally low, ranging from $\mathrm{pH}$ 4-6. In Sphagnum moss peat those values are even known to reach as low as $\mathrm{pH} 3-4$. In this respect the presence in a peat bog of GDGT 6, derived from methanogenic archaea, might be not surprising as monolayer membranes composed of isoprenoid GDGTs provide an excellent barrier against the high proton gradients present in acidic environments (Elferink et al., 1994; Van de Vossenberg et al., 1998). Indeed, Macalady and colleagues (2004) recently showed that there is a better correspondence between the occurrence of GDGT lipids and the degree of acidity than between the occurrence of GDGT lipids and temperature in a series of 49 archaeal species. Membrane lipids of acidophilic archaea were composed of up to $100 \%$ of GDGTs, whereas no GDGTs were detected in the three alkaliphilic archaea studied. Thus, although possessing branched instead of isoprenoid alkyl chains, the occurrence of branched tetraether lipids in anaerobic bacteria in peat bogs could well be related to the more acidic $\mathrm{pH}$ conditions in such an environment.

\section{Conclusions}

Branched GDGT membrane lipids (7-15) are shown to have an 1,2-di-O-alkyl-sn-glycerol stereoconfiguration. This feature, in combination with the characteristic branched alkyl chains, forms convincing evidence that branched GDGTs are biosynthesized by Bacteria. Furthermore, it has been unequivocally proven that branched
GDGTs contain up to two cyclopentyl moieties. This is the first report of the occurrence of membrane-spanning tetraether lipids and the capability to form cyclopentyl moieties in core membrane lipids in the domain of Bacteria. Although the exact source of the branched GDGT lipids remains, as yet, unknown, they are abundant in the anoxic parts of peat bogs. As the abundance of branched GDGTs covary in two depth profiles with that of GDGT 6, derived from anaerobic methanogens, a similar ecological niche for the methanogenic Archaea and the anaerobic, branched GDGT producing bacteria is expected. The biological function of branched GDGTs in the bacteria is unknown, but their presence could well be related to the acidic conditions in a peat bog.

\section{Experimental procedures}

\section{Sites and sampling}

Peat cores for GDGT analysis were taken from the Saxnäs Mosse in Sweden and the Bolton Fell Moss in England. The Saxnäs Mosse area (SW Sweden, $5651^{\prime 2} 20.78^{\prime \prime} \mathrm{N}, 13$ $27^{\prime} 39.62^{\prime \prime} \mathrm{E}$ ) is an ombrotrophic raised bog with vegetation mainly composed of Sphagnum species. The upper $25 \mathrm{~cm}$ constitute the acrotelm layer in which the water table fluctuates. Below $25 \mathrm{~cm}$ the peat bog is continuously water saturated and consequently anoxic. A $50 \mathrm{~cm}$ long core was taken with a Wardenaar peat profile sampler and subsamples were taken at a $2 \mathrm{~cm}$ interval.

The Bolton Fell Moss (National Grid Reference NY 495695, Cumbria, England) is a large ombrotrophic mire with a raised central dome with an average depth of $6 \mathrm{~m}$ and vegetation currently dominated by Sphagnum species (Xie et al., 2004). The acrotelm/catotelm boundary was determined at about $30 \mathrm{~cm}$ depth. A $50 \mathrm{~cm}$ monolith was collected alongside a $5 \mathrm{~m}$ Russian core covering a depth range of 25$500 \mathrm{~cm}$; these were then subsectioned in $1 \mathrm{~cm}$ intervals and combined. A total of 50 subsamples were taken from the upper $175 \mathrm{~cm}$.

Bulk peat samples for isolation of GDGT 10 were taken from Étang de la Gruère in the Jura Mountains of Switzerland. Étang de la Gruère is a strongly domed, raised bog with a peat accumulation of more than $6 \mathrm{~m}$ (Steinmann and Shotyk, 1997). About $2.5 \mathrm{~kg}$ of peat (wet weight) was collected with a Belorussian peat sampler from a depth of $4.75-5.25 \mathrm{~m}$.

\section{Sample preparation}

Peat samples were freeze dried and powdered with a mortar prior to extraction by an accelerated solvent extractor (ASE 200, DIONEX), soxhlet or by sonication, with solvent mixtures composed of dichloromethane and methanol. The obtained total extracts were prepared further for GDGT analysis as described earlier (Hopmans et al., 2000)

\section{Preparative HPLC}

Isolation of GDGT 10 was achieved by semi-preparative HPLC followed by flow injection analysis according to Smit- 
tenberg and colleagues (2002). The columns used are a semi-preparative and an analytical Alltech Prevail Cyano column $\left(250 \mathrm{~mm} \times 10 \mathrm{~mm}\right.$; $5 \mu \mathrm{m}$; flow rate $3 \mathrm{ml} \mathrm{min}^{-1}$ and $250 \mathrm{~mm} \times 4,6 \mathrm{~mm} ; 5 \mu \mathrm{m}$; flow rate $1 \mathrm{ml} \mathrm{min}^{-1}$ respectively).

\section{HPLC/APCI-MS}

Glycerol dialkyl glycerol tetraethers were analysed and quantified by high-performance liquid chromatography/ atmospheric pressure chemical ionization mass spectrometry (HPLC/APCI-MS), according to Hopmans and colleagues (2000) with minor modifications. Analyses were performed on an Agilent 1100 series/1100MSD series machine, equipped with auto-injector and HP Chemstation software. Separation was achieved on an Alltech Prevail Cyano column (150 mm $\times$ $2.1 \mathrm{~mm} ; 3 \mu \mathrm{m})$. The flow rate of the hexane : propanol (99:1, $\mathrm{v} / \mathrm{v}$ ) eluent was $0.2 \mathrm{ml} \mathrm{min}^{-1}$, isocratically for the first $5 \mathrm{~min}$, thereafter with a linear gradient to $1.8 \%$ propanol in $45 \mathrm{~min}$. Injection volume of the samples was $10 \mu \mathrm{l}$. Quantification of the GDGT compounds was achieved by integrating the peak areas in the $[\mathrm{M}+\mathrm{H}]^{+}$and $[\mathrm{M}+\mathrm{H}]^{+}+1$ ion traces (i.e. protonated molecule and first isotope peak) and comparing these to an external calibration curve prepared with known amounts of pure crenarchaeol (17). A correction was made for the branched GDGTs (7-15), as their molecular mass is lower than that of crenarchaeol.

\section{High temperature-gas chromatography}

Bolton Fell Moss samples were analysed by high temperature-gas chromatography (HT-GC) performed on a Hewlett Packard 5890 Series II GC, equipped with a flame ionization detector. Samples were run over an SGE HT5 (5\% phenyl equivalent, polycarborane siloxane), $6 \mathrm{~m}$ by $0.53 \mathrm{~mm}$ aluminium clad column. The following temperature program was used for most analyses: $50^{\circ} \mathrm{C}(1 \mathrm{~min})$ to $140^{\circ} \mathrm{C}$ at $20^{\circ} \mathrm{C}$ $\mathrm{min}^{-1}$ followed by $140^{\circ} \mathrm{C}$ to $420^{\circ} \mathrm{C}(10 \mathrm{~min})$ at $7^{\circ} \mathrm{C} \mathrm{min}^{-1}$. Glycerol dialkyl glycerol tetraether peaks were identified based on comparisons with standards $\left(2,3,2^{\prime}, 3^{\prime}\right.$-tetra-Odibiphytanyl-di-sn-glycerol-1'- $\beta$-gulosyl-1-phosphoryl-3" -snglycerol sodium salt standard, subsequently converted into a GDGT; Universal Biologicals), and GDGTs identified in cold seep samples using LC-MS (Zhang et al., 2003). Interpretations were then validated by comparison with GC-MS analyses of selected $\mathrm{HI}^{-\mathrm{LiAlH}_{4}}$ treated samples.

\section{Nuclear magnetic resonance}

${ }^{1} \mathrm{H}$ - and ${ }^{13} \mathrm{C}$-NMR spectroscopy was performed on a Bruker DMX-600 spectrometer as described previously (Sinninghe Damsté et al., 2002a). ${ }^{19} \mathrm{~F}$-NMR spectroscopy of the Mosher derivatives of GDGTs were performed on a Varian Unity Inova 500, as described previously (Sinninghe Damsté et al., 2004).

\section{Acknowledgements}

Dr P. Steinmann is gratefully thanked for his assistance with sampling at Étang de la Gruère. We are indebted to Dr B. van Geel and $M$. van der Linden for providing peat samples from the Saxnäs Mosse, and to Professor R.P. Evershed and Dr F. Volders for providing samples from Bolton Fell Moss. M. Rietkerk is thanked for analytical assistance with the HPLCMS equipment and $\mathrm{Dr} \mathrm{E}$. DeLong and two anonymous reviewers for providing constructive comments on this manuscript. This research is funded by the Research Council for Earth and Life Sciences (ALW) of the Netherlands Organization for Scientific Research (NWO).

\section{References}

Boucher, Y., Kamekura, M., and Doolittle, W.F. (2004) Origins and evolution of isoprenoid lipid biosynthesis in archaea. Mol Microbiol 52: 515-527.

Carballeira, N.M., Reyes, M., Sostre, A., Huang, H., Verhagen, M.F.J.M., and Adams, M.W.W. (1997) Unusual fatty acid composition of the hyperthermophilic archaeon Pyrococcus furiosus and the bacterium Thermotoga maritima. J Bacteriol 179: 2766-2768.

Dale, J.A., and Mosher, H.S. (1973) Nuclear magneticresonance enantiomer reagents - configurational correlations via nuclear magnetic-resonance chemical-shifts of diastereomeric mandelate, O-methylmandelate, and alpha-methoxy-alpha-trifluoromethylphenylacetate (Mtpa) esters. J Am Chem Soc 95: 512-519.

DeLong, E.F., King, L.L., Massana, R., Cittone, H., Murray, A., Schleper, C., and Wakeham, S.G. (1998) Dibiphytanyl ether lipids in nonthermophilic Crenarchaeotes. Appl Environ Microbiol 64: 1133-1138.

De Rosa, M., de Rosa, S., and Gambacorta, A. (1977) ${ }^{13} \mathrm{C}$ NMR assignments and biosynthetic data for the ether lipids of Caldariella. Phytochemistry 16: 1909-1912.

De Rosa, M., Gambacorta, A., Huber, R., Lanzotti, V., Nicolaus, B., Stetter, K.O., and Trincone, A. (1988) A new 15,16-dimethyl-30-glyceryloxytriacontanoic acid from lipids of Thermotoga maritima. Chem Commun 1988: 1300-1301.

Eguchi, T., Nishimura, Y., and Kakinuma, K. (2003) Importance of the isopropylidene terminal of geranylgeranyl group for the formation of tetraether lipid in methanogenic archaea. Tetrahedron Lett 44: 3275-3279.

Elferink, M.G.L., Dewit, J.G., Driessen, A.J.M., and Konings, W.N. (1994) Stability and proton-permeability of liposomes composed of archaeal tetraether lipids. Biochim Biophys Acta 1193: 247-254.

Hoefs, M.J.L., Schouten, S., De Leeuw, J.W., King, L.L., Wakeham, S.G., and Sinninghe Damsté, J.S. (1997) Ether lipids of planktonic Archaea in the marine water column. Appl Environ Microbiol 63: 3090-3095.

Hopmans, E.C., Schouten, S., Pancost, R.D., Van der Meer, M.T.J., and Sinninghe Damsté, J.S. (2000) Analysis of intact tetraether lipids in archaeal cell material and sediments by high performance liquid chromatography/ atmospheric pressure chemical ionization mass spectrometry. Rapid Commun Mass Spectrom 14: 585-589.

Hopmans, E.C., Weijers, J.W.H., Schefuss, E., Herfort, L., Damste, J.S.S., and Schouten, S. (2004) A novel proxy for terrestrial organic matter in sediments based on branched and isoprenoid tetraether lipids. Earth Planet Sci Lett 224: 107-116.

Huber, R., Wilharm, T., Huber, D., Trincone, A., Burggraf, S., König, H., et al. (1992) Aquifex pyrophilus gen. nov. sp. 
nov., represents a novel group of marine hyperthermophilic hydrogen-oxidizing bacteria. Syst Appl Microbiol 15: 340351.

Huber, R., Rossnagel, P., Woese, C.R., Rachel, R., Langworthy, T.A., and Stetter, K.O. (1996) Formation of ammonium from nitrate during chemolithoautotrophic growth of the extremely thermophilic bacterium Ammonifex degensii gen.nov.sp.nov. Syst Appl Microbiol 19: 40-49.

Jung, S., Zeikus, J.G., and Hollingsworth, R.I. (1994) A new family of very long chain $\alpha, \omega$-dicarboxylic acids is a major structural fatty acyl component of the membrane lipids of Thermoanaerobacter ethanolicus 39E. J Lipid Res 35: 1057-1065.

Kates, M. (1978) The phytanyl ether-linked polar lipids and isoprenoid neutral lipids of extremely halophilic bacteria. Prog Chem Fats Other Lipids 15: 301-342.

Kito, M., and Pizer, L.I. (1969) Purification and regulatory properties of biosynthetic L-glycerol 3-phosphate dehydrogenase from Escherichia coli. J Biol Chem 244: 33163323.

Koga, Y., Kyuragi, T., Nishihara, M., and Sone, N. (1998) Did archaeal and bacterial cells arise independently from noncellular precursors? A hypothesis stating that the advent of membrane phospholipid with enantiomeric glycerophosphate backbones caused the separation of the two lines of descent. J Mol Evol 46: 54-63.

Kotsyurbenko, O.R., Chin, K.J., Glagolev, M.V., Stubner, S., Simankova, M.V., Nozhevnikova, A.N., and Conrad, R. (2004) Acetoclastic and hydrogenotrophic methane production and methanogenic populations in an acidic WestSiberian peat bog. Environ Microbiol 6: 1159-1173.

Langworthy, T.A., Holzer, G., Zeikus, J.G., and Tornabene, T.G. (1983) Iso- and anteiso-branched glycerol diethers of the thermophilic anaerobe Thermodesulfotobacterium commune. Syst Appl Microbiol 4: 1-17.

Lee, S., Kang, S., Kim, J.N., and Jung, S. (2002) Structural analyses of the novel phosphoglycolipids containing the unusual very long bifunctional acyl chain, $\alpha, \omega-13,16-$ dimethyloctacosanedioate in Thermoanaerobacter ethanolicus. Bull Korean Chem Soc 23: 1778-1784.

Macalady, J.L., Vestling, M.M., Baumler, D., Boekelheide, N., Kaspar, C.W., and Banfield, J.F. (2004) Tetraether-linked membrane monolayers in Ferroplasma spp: a key to survival in acid. Extremophiles 8: 411-419.

Nelson, K.E., Clayton, R.A., Gill, S.R., Gwinn, M.L., Dodson, R.J., Haft, D.H., et al. (1999) Evidence for lateral gene transfer between Archaea and Bacteria from genome sequence of Thermotoga maritima. Nature 399: 323-329.

Nemoto, N., Shida, Y., Shimada, H., Oshima, T., and Yamagishi, A. (2003) Characterization of the precursor of tetraether lipid biosynthesis in the thermoacidophilic archaeon Thermoplasma acidophilum. Extremophiles 7: 235-243.

Nishihara, M., and Koga, Y. (1995) Sn-glycerol-1-phosphate dehydrogenase in Methanobacterium thermoautotrophicum - key enzyme in biosynthesis of the enantiomeric glycerophosphate backbone of ether phospholipids of Archaebacteria. J Biochem 117: 933-935.

Pancost, R.D., and Sinninghe Damsté, J.S. (2003) Carbon isotopic compositions of prokaryotic lipids as tracers of carbon cycling in diverse settings. Chem Geol 195: 29-58.
Pancost, R.D., Van Geel, B., Baas, M., and Sinninghe Damsté, J.S. (2000) $\delta^{13} \mathrm{C}$ values and radiocarbon dates of microbial biomarkers as tracers for carbon recycling in peat deposits. Geology 28: 663-666.

Pancost, R.D., Bouloubassi, I., Aloisi, G., Sinninghe Damsté, J.S., and the Medinaut Shipboard Scientific Party (2001) Three series of non-isoprenoidal dialkyl glycerol diethers in cold-seep carbonate crusts. Org Geochem 32: 695707.

Rütters, H., Sass, H., Cypionka, H., and Rullkotter, J. (2001) Monoalkylether phospholipids in the sulfate-reducing bacteria Desulfosarcina variabilis and Desulforhabdus amnigenus. Arch Microbiol 176: 435-442.

Schouten, S., Hopmans, E.C., Pancost, R.D., and Sinninghe Damsté, J.S. (2000) Widespread occurrence of structurally diverse tetraether membrane lipids: evidence for the ubiquitous presence of low-temperature relatives of hyperthermophiles. Proc Natl Acad Sci USA 97: 14421-14426.

Sinninghe Damsté, J.S., Hopmans, E.C., Pancost, R.D., Schouten, S., and Geenevasen, J.A.J. (2000) Newly discovered non-isoprenoid glycerol dialkyl glycerol tetraether lipids in sediments. Chem Commun 2000: 1683-1684.

Sinninghe Damsté, J.S., Schouten, S., Hopmans, E.C., Van Duin, A.C.T., and Geenevasen, J.A.J. (2002a) Crenarchaeol: the characteristic core glycerol dibiphytanyl glycerol tetraether membrane lipid of cosmopolitan pelagic crenarchaeota. J Lipid Res 43: 1641-1651.

Sinninghe Damsté, J.S., Strous, M., Rijpstra, W.I.C., Hopmans, E.C., Geenevasen, J.A.J., Van Duin, A.C.T., et al. (2002b) Linearly concatenated cyclobutane lipids from a dense bacterial membrane. Nature 419: 708-712.

Sinninghe Damsté, J.S., Rijpstra, W.I.C., Strous, M., Jetten, M.S.M., David, O.R.P., Geenevasen, J.A.J., and Van Maarseveen, J.H. (2004) A mixed ladderane/n-alkyl glycerol diether membrane lipid in an anaerobic ammoniumoxidizing bacterium. Chem Commun 2004: 2590-2591.

Smittenberg, R.H., Hopmans, E.C., Schouten, S., and Sinninghe Damsté, J.S. (2002) Rapid isolation of biomarkers for compound specific radiocarbon dating using highperformance liquid chromatography and flow injection analysis-atmospheric pressure chemical ionisation mass spectrometry. J Chromatogr A 978: 129-140.

Steinmann, P., and Shotyk, W. (1997) Geochemistry, mineralogy, and geochemical mass balance on major elements in two peat bog profiles (Jura Mountains: Switzerland). Chem Geol 138: 25-53.

Stern, J., Freisleben, H.J., Janku, S., and Ring, K. (1992) Black lipid-membranes of tetraether lipids from Thermoplasma acidophilum. Biochim Biophys Acta 1128: 227236.

Tornabene, T.G., and Langworthy, T.A. (1979) Diphytanyl and dibiphytanyl glycerol ether lipids of methanogenic archaebacteria. Science 203: 51-53.

Torsvik, V., Øvreås, L., and Thingstad, T.F. (2002) Prokaryotic diversity - magnitude, dynamics, and controlling factors. Science 296: 1064-1066.

Van de Vossenberg, J.L.C.M., Driessen, A.J.M., and Konings, W.N. (1998) The essence of being extremophilic: the role of the unique archaeal membrane lipids. Extremophiles 2: 163-170. 
Woese, C.R., Kandler, O., and Wheels, M.L. (1990) Towards a natural system of organisms: proposal for the domains Archaea, Bacteria, and Eucarya. Proc Natl Acad Sci USA 87: 4576-4579.

Xie, S., Nott, C.J., Avsejs, L.A., Maddy, D., Chambers, F.M., and Evershed, R.P. (2004) Molecular and isotopic stratig- raphy in an ombrotrophic mire for paleoclimate recontruction. Geochim Cosmochim Acta 68: 2849-2862.

Zhang, C.L., Pancost, R.D., Sassen, R., Qian, Y., and Macko, S.A. (2003) Archaeal lipid biomarkers and isotopic evidence of anaerobic methane oxidation associated with gas hydrates in the Gulf of Mexico. Org Geochem 34: 827-836.

\section{Appendix}

Structures of the GDGTs and some other membrane lipids discussed in the text.
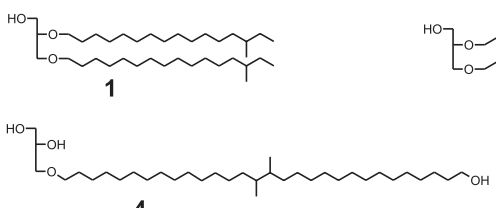

4
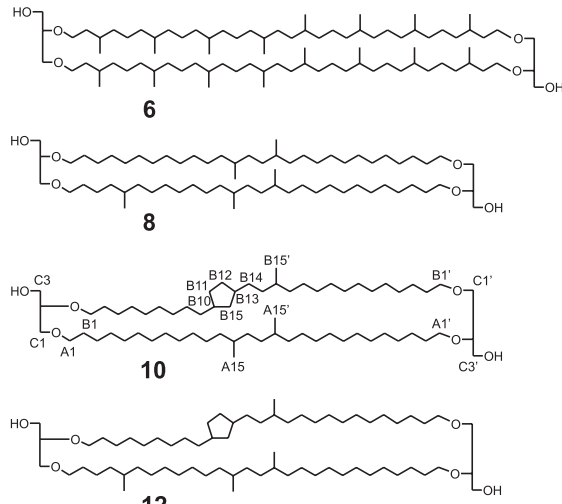

12

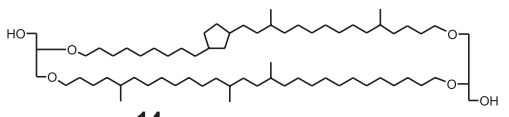

14

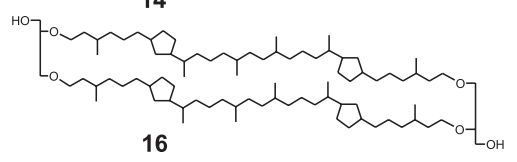

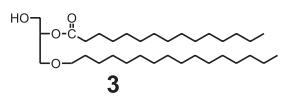
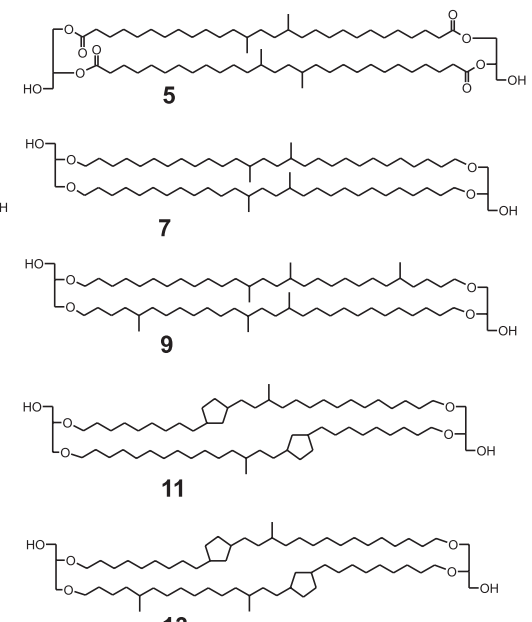

13

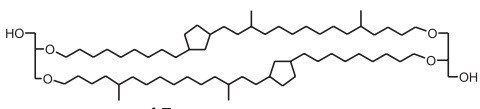

15

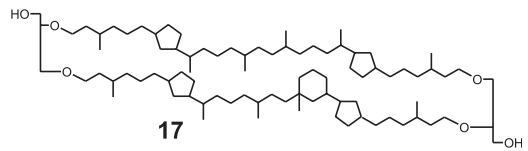

